\section{Masculinity and Suicide in Bangladesh}

OMEGA_Journal of Death and Dying

(C) The Author(s) 2020

Article reuse guidelines: sagepub.com/journals-permissions DOI: $10.1177 / 0030222820966239$

journals.sagepub.com/home/ome

@SAGE

\author{
Anisur Rahman Khan' (D, \\ Kopano Ratele ${ }^{2}$, Rebecca Helman², \\ Sipho Dlamini ${ }^{2}$, and Refiloe Makama ${ }^{2}$
}

\begin{abstract}
Suicide is a serious but under-researched public health problem in Bangladesh. In light of this, we sought to explore the association between masculinities and suicide. We interviewed 20 family members/friends of men who died by suicide across 12 rural areas of the Jhenaidah district, Bangladesh. We found that male suicide was attributed to men's inability to fulfil hegemonic masculine demands such as financial provision and meeting the sexual needs of their spouses. Suicide was also linked to men's loss of self-respect and respect from others. Some participants mentioned that men committed suicide as an act of self-sacrifice, while others cited mental and physical illness. As a result of these findings, we propose that addressing sociocultural and religious issues associated with men's troubles may help to prevent suicide. At the same time, changing the restrictive gender roles and masculinityrelated ideals is also needed to counter the problem.
\end{abstract}

\title{
Keywords
}

suicide, hegemonic masculinity, crisis, gender roles, Bangladesh

\footnotetext{
'Department of Sociology, East West University, Dhaka, Bangladesh

${ }^{2}$ Masculinity and Health Research Unit, South African Medical Research Council-University of South Africa/Institute for Social and Health Sciences, University of South Africa, Cape Town, South Africa

Corresponding Author:

Anisur Rahman Khan, Department of Sociology, East West University, Dhaka, Bangladesh.

Email: arkhan@ewubd.edu
} 


\section{Masculinity and Suicide in Bangladesh}

Throughout the world, suicide is a major public health burden and a significant cause of premature death (Scourfield \& Evans, 2015; White et al., 2016). Estimates are that close to 800,000 people worldwide die by suicide every year (World Health Organization [WHO], 2017). Whilst suicide is a deliberate choice or behaviour of the individual (Jaworski, 2010), it is also a complex and multifarious phenomenon, often embedded in a wide range of socio-cultural and religious contexts and perspectives (Platt, 2017; Scourfield \& Evans, 2015). Thus, a nuanced understanding of suicide is never possible through a single, fixed or acontextual framework (White et al., 2016).

Globally, men typically have higher rates of suicide than women (Demir, 2018), even though women attempt suicide more often than men (Vijayakumar, 2015). Male suicide rates exceed female rates by as much as 2.98 times in all age groups except the 15 to 19 age group (Naghavi, 2019). Given that globally more males than females die as a result of suicide, a need exists to explore the link between suicide and gender (Bantjes \& Kagee, 2013). The socio-cultural - including religious notions that prevail in society - and gender context of male suicide can be better understood by broadly examining men's social position and experiences from a critical masculinity perspective (Andoh-Arthur et al., 2018; Knizek \& Hjelmeland, 2018). Excessive social and cultural expectations to conform to the traditional norms of masculinity may heighten the risk of men's suicidal behaviour (Pirkis et al., 2017; Struszczyk et al., 2019). Considering the higher global trend of male suicide, investigations about male suicidal behaviour have significant implications with regards to prevention interventions as well (Struszczyk et al., 2019).

In Bangladesh more than 10,000 people are estimated to die due to suicide; the average is 7.3 per 100,000 people per year. The suicide rate is 17 times higher in the rural population than the urban population (Mashreky et al., 2013). Contrary to the global pattern, in Bangladesh more women than men die by suicide (Salam et al., 2017). The rate of suicide is 6.5 per 100,000 for men and 8.2 per 100,000 for women (Mashreky et al., 2013).

The dominant faith in Bangladesh is Islam (with Muslims comprising 90.4\% of the country) (Bangladesh Bureau of Statistics, 2015). Suicide is prohibited or condemned in Islam, but martyrdom (self-sacrifice) for the sake of the religion is admired as being a strong sign of masculine/active act (Hamamra, 2018). Countries in which the dominant faith is Islam consistently show lower rates of suicide compared to other parts of the world, although strong social stigma, religious and culture prohibitions against suicide are likely to contribute to under-reporting in these contexts (Gearing \& Alonzo, 2018; Gearing \& Lizardi, 2009; Koenig \& Al Shohaib, 2014; Lester, 2006). Similarly, in Bangladesh people are likely to hide evidence of suicide, thereby making it difficult to generate reliable estimates of suicide deaths in the country (Khan et al., 
2020a; Arafat et al., 2020). Moreover, the dearth of empirical literature precludes an accurate picture of the dynamics and risk factors of suicide in these countries (Gearing \& Alonzo, 2018; Sherman et al., 2008). By examining the relationship between suicide rate and percentage of adherents to Islam using WHO data repository for 27 countries, Shah and Chandia (2010) found the median rates of suicide for men and women across all countries was 19.8 for men and 4.7 for women per 100,000 population. Although caution is necessary in interpreting the relationship between masculinity and men's suicide in Muslim countries, the elevated prevalence of male suicide suggests the need to make masculinity as a central focus in term of research and policy imperatives in a country like Bangladesh where the dominant faith is Islam.

Although there are higher incidences of reported suicide amongst women in Bangladesh, the present study investigated how male suicide could possibly be associated with dominant notions of traditional masculinity. WHO's data on age-standardised suicide rates (per 100,000 population) confirm that over the years there has been a steady increase in male suicide rates and a sharp decline in female rates in Bangladesh (WHO, n.d.). Moreover, a recent community-based trend analysis conducted between 2010 and 2018 in the Jhenaidah district of Bangladesh, the most suicide-prone area in the country, indicates an upsurge in male suicide rates and decrease in female suicide rates ( Khan et al., 2020a). In light of these findings, as well as the higher global trend of male suicide, understanding the risks factors associated with masculinity might provide important opportunities and directions for future suicide prevention and intervention in the context of Bangladesh.

Globally, there is a substantial literature on suicidal behaviour using quantitative methods (Latakiene \& Skruibis, 2015). While there is growing trend of qualitative research towards advancing knowledge regarding suicide (see Bantjes \& Swartz, 2017), this trend has not been observed in Bangladeshi suicidal scholarship. Specifically, there is no post hoc qualitative study that has examined the experiences and narratives of persons whose close relatives or friends died by suicide in Bangladesh. Interviews with "friends and family members who experienced a loss to suicide could offer much-needed data" (Wray et al., 2011 , p. 522), thereby helping to inform context-based prevention and intervention strategies (Andoh-Arthur et al., 2018).

In order to deepen an understanding of the context of male suicide in Bangladesh, this article draws on Connell's (1995) concept of hegemonic masculinity. A socially privileged category, hegemonic masculinity is a gendered practice that provides explanations of the legitimacy of patriarchy and ensures the dominant position of men over women (Connell, 1995; Rivers, 2014). Masculinities are organised in a hierarchy, with hegemonic masculinity sitting at the top, and subordinate, complicit, and marginalised below this exalted model of masculinity (Connell, 1995). Although versions of hegemonic masculinity differ from context to context, research has demonstrated how, within a 
global capitalist economy, financial provision is a defining feature of hegemonic masculinity (Clowes et al., 2013 ; Dermott, 2008). In light of the socio-cultural constitution of masculinities, a qualitative research approach is particularly useful in examining the salient ideas and configurations of masculinities in relation to suicide (Canetto \& Clearly, 2012).

In examining the relationship between masculinity and male suicide one of the objectives is to comprehend how the hegemonic version of masculinity could be health-damaging (Scourfield, 2005). Men often struggle to enact the hegemonic model of masculinity and feel ashamed when they cannot maintain hegemonic masculine norms (Canetto \& Clearly, 2012). Due to macro-social changes men may lose their positions as sole breadwinners or providers and their position in the household, workplace, society and community leading to frustration and depression (Rutz \& Rihmer, 2007). The loss of power, social position, and gender identity among some men leads to inward rage which might end in suicide (Morgan, 2006). In this regard, some men who fail to attain masculine ideals may be at greater risk of suicide (Mansdotter et al., 2009). In some instances, suicide is a way out of being unable to live up to the demands of hegemonic masculinity (Rivers, 2014). Therefore, the increased or high male suicide rates may be closely associated with the reported crisis of masculinity (Scourfield, 2005).

There is a relative dearth of empirical and theoretical literature on men and masculinity in Bangladesh (Sowad, 2017). This makes it difficult to grasp the ideal and changing meanings of Bangladeshi masculinity. However, the limited research that does exist suggests that Bangladeshi masculinities are influenced by socioeconomic status, religion, cultural traditions, and social generation (Doneys, 2013; Hasan et al., 2018). Specifically, masculinities in Bangladesh can be constructed in relation to a threefold criterion: real men (hegemonic masculinity), good man (subordinated masculinity) and ordinary men (marginalised masculinity) (Doneys, 2013; Imtiaz, 2013). The category of 'real men' includes being the sole income earner and primary provider within family, being dominant and powerful, having complete authority over family matters, enacting physical and sexual competence, maintaining family honour and restricting women's mobility (Anwary, 2015; Hasan et al., 2018; Imtiaz, 2013; Khan \& Townsend, 2014; Khan et al., 2008). The key features of subordinated and marginalised form of masculinities in Bangladesh include men who fail to adhere to the category of 'real men', including sexual minorities, non-violent and socially and environmentally conscious men, and men whose masculinities are viewed by others as different (Doneys, 2013). Across Bangladeshi literature, there is no evidence of an exploration into the ways in which (hegemonic) masculinity is related to male suicide. Within this context, our research contributes to theoretical and methodological understandings of suicide by investigating the relationship between masculinity and suicide. 


\section{Research Process}

\section{Study Location}

The study was conducted in the rural settings of the Jhenaidah district, located in the southwest region Bangladesh where suicide rates are extremely high (Khan et al., 2020b). Between 2010 and 2018, 3,152 suicides were officially recorded in this district (Khan et al., 2020a). Using referrals from Society for Voluntary Activities (SOVA), the only non-profit organisation working in this district to reduce suicide (Khan et al., 2020c), we purposefully located 20 male suicide cases from 12 rural areas.

\section{Participants}

For each suicide death, we interviewed one person close to the deceased person (father, mother, spouse, brother, sister-in-law or close friend). In order to be interviewed participants had to be 18 years or older, and have lived in the same household (for family members) or had intimate contact (for close friends) with the man who committed suicide before death. Participants were related to the deceased persons in the following ways: 6 were wives, 4 were mothers, 4 were fathers, 3 were sisters-in-law, 2 were close friends and 1 was a brother. Three (3) participants were between 21-30, 3 were $31-40$ years, 8 were $41-50$ years, and 6 were 51 years and older.

The 20 men who had committed suicide were between the ages of 17 and 55 . In terms of religion, 18 were Muslims and 2 were Hindus. Fifteen were married and 5 were unmarried. Of the married men, 11 had between 1 and 4 children and 4 men had no children. Two (2) of the men had tertiary education, 8 had high school education, 8 had elementary school education, and 2 had no education. Nine (9) men had been farmers, 8 self-employed, 2 students, and 1 unemployed. Income ranged between Bangladeshi Taka 7,000 and 20,000 per month (approximately USD83 to USD236). The methods of suicide were hanging (13), poison or insecticide ingestion (6), and jumping (1). One man had attempted suicide previously. All the deaths occurred between 2014 and 2018.

\section{Procedure}

The first author conducted the interviews, using a semi-structured interview schedule, between December 2018 and February 2019. Broadly, he asked the participants to share their perceptions and experiences about the suicidal deaths of men, with particular focus on the men's ideas and practices related to masculinity. Although the interviewer used the interview schedule as a guide, he encouraged participants to share freely what they regarded as the most relevant or significant details about the suicide incidents in relation to masculinity. The interview schedule included several guiding items such as perceptions of 
(hegemonic) masculinity and men's gender roles in society, perceptions about men's suicide in general, perceptions and experiences of the particular suicide case in relation with the victim's subscription to or failure in relation to the prevalent ideals of (hegemonic) masculinity and men's gender roles.

At the beginning of the interview, the interviewer asked each participant to provide demographic information about the victim. Since discussing suicide is a sensitive and emotional issue, the interviewer spent a considerable amount of time gaining the trust of the participants through building appropriate rapport. Interviews lasted 35 to 90 minutes and were conducted in the local language, Bangla. The interviewer audio-recorded the interviews with the permission of the participants. The interviews were conducted at a preferred time and place of the participants.

\section{Data Analysis}

The first author and a research assistant from Bangladesh transcribed the interviews, which were then translated into English by two professional translators. We then used a phenomenological qualitative approach to understand the deep meaning of victims' experiences as relayed in the interviews (Rossman \& Rallis, 2012). In suicide research, the phenomenological approach allows for a more nuanced understanding of the context of suicide, through a focus on unique experiences (Pompili, 2018).

We used the thematic analytical procedure suggested by Braun and Clarke (2006) to analyse the interview transcripts. All the researchers read the interview transcripts several times then grouped all the similar patterns together as themes. All the transcripts were treated as equally important. Our analysis was informed by the relevant empirical and theoretical literature related to suicide and masculinities. Broadly, the analysis was informed by the overarching research question: How is (hegemonic) masculinity linked to men's suicide?

\section{Research Ethics}

The research received ethical clearance from the University of South Africa (Ethical Clearance Code: 2018-CHS-0114). Before beginning, the interviewer briefed the participants about their rights as well as the risks of participating. Participants were assured of confidentiality for themselves and the deceased persons. Because recollecting memories of suicidal incidents can be traumatic, a trained counsellor accompanied the interviewer during the data collection. In addition, we made transport available for the participants should they have needed to be taken to the hospital during the course of the interviews. However, no participant needed any counseling or immediate transportation to the hospital. 


\section{Results}

Through the analysis process six themes were constructed from the material, namely: failing providers, relationship strain, sexual impotency and infidelity, personal sacrifice for the good and stability of the family, loss of masculine selfesteem and respect, as well as physical and mental illness. All of the themes seem to be related to a certain crisis of traditional masculinity, some much more directly than others. Below we discuss each theme, using examples from the transcripts to illustrate each theme.

\section{Failing Providers}

A key theme in the interviews was men's inability to meet the socially prescribed responsibility to be the family's primary provider. In order to enjoy the benefits of 'patriarchal dividend' (Connell, 1995), it is imperative for men to affirm their status by positioning themselves as the perfect breadwinner (Rivers, 2014). Having money and work is an important symbol of demonstrating a traditional hegemonic model of masculinity (Scourfield et al., 2012). Several men encountered troubles in maintaining such a hegemonic provider identity. Failure to provide not only produced conflicts in the family, but it also seemed to have generated a crisis for men, diminishing their socio-cultural (and religious) position. Spouses like Sultana, Dolly and Apu reflected on the link between the suicidal episode and their husband's inability to provide:

Money is the husband of a man. [-] I would quarrel with him and used to tell him he is not a man who cannot earn a livelihood (Sultana).

Since he could not manage the family properly, I used to quarrel with him. Definitely, that was my mistake (Dolly).

I used to tell him to be wise financially, but he was unable to do so. [-] I used to lose my temper on him for this reason. [-] To be honest, he was very poor in managing his finances; he did not truly understand his own responsibilities towards his family. We spent more than we earned (Apu).

Other participants also indicated the difficulties related to men's ability to provide. For example, Zohur and Johny's relatives reported that they could not settle in any occupation or business and therefore could not provide support to their families.

I see him as a failed man. No control over himself. (Shifa, Zohur's sister-in-law)

His [Johny's] mother struggled so hard in her life to maintain the family and to provide education to her two sons (Johny and his brother). At one point in time, he 
realised that he had failed as a man as he is unable to support his mother or family financially. They used to live in deep financial troubles. It was a kind of soreness for him. He was in a state of deep frustration. (Borhan, Johny's close friend)

Some men's suicidal decisions appeared to be provoked by being trapped in debt. As a result of the debt burden, men experienced inner turmoil fueled by frustration and shame. Participants provided examples of how the problems experienced by the men were due to having high levels of debt. For example, Mostofa, the family's eldest son, experienced a downward spiral in business and could not cover the business loan repayments. Simultaneously, he also failed to cover the loan he had for performing Hajj (pilgrimage) in Mecca with his mother. Manik, one of his best friends, said:

For the last few months, I observed he (Mostofa) was so depressed. Several times, I advised him to visit a doctor. But he used to say that it is better to die than live on when you have a lot of complexities in life. [-] Surprisingly, a week before the incident of suicide, he began to behave so peculiarly. He even started to misbehave with his creditors. He used to do whatever he liked. As he was not being able to recover the loan an estranged relationship developed with all his creditors. Meaning that he had made a choice of taking his own life.

Similarly, Hiron's suicidal context demonstrates the deep crisis of masculinity which perhaps gives rise to feelings of shame and despair associated with failure to be a provider. Following a family decision to increase income by starting a business, his wife, Greta, borrowed a substantial amount of money from an NGO. Ultimately, the business did not flourish as expected. Therefore, they were unable to cover the loan. When the NGO official threatened to have Greta arrested, Hiron felt humiliated and killed himself shortly after this. Greta, narrated the situation:

It is nothing but an expression of great humiliation for him. At one point, he was scared if the Police come in the morning what would happen. On the other point, he thought himself as a failed person as he could not perform the responsibilities as a man what were supposed to perform. He could not bear the turmoil.

\section{Relationship Strain}

Disturbed relationships, particularly with spouses, were reported as resulting in men's pain, loss and anger. Although relationship strain is commonly found as a critical risk factor for suicidal behaviour (Knizek \& Hjelmeland, 2018), most of the evidence confirms that men are at a greater risk of suicide in the event of relationship strain (Evans et al., 2016). Moreover, as Clearly (2019) notes, the 
social prohibition of men's emotional expression has been identified as contributing to men's suicide. Thus, men's pain, which may be unexpressed, may operate as a critical risk factor for suicide.

For example, Zohur, a highly educated man, experienced serious relationship troubles with his wife. His educational expenses were borne by his elder brother and elder-sister-in-law. In return, he took the responsibility to educate his elder brother's daughter. This created contention between Zohur and his wife. This conflict was reported to have resulted in Zohur hanging himself. Shufia, a sister-in-law of Zohur explained:

Once he (Zohur) got a job at a Bank, he started helping my daughter financially who is now a medical doctor. He kept her at his workplace. But his wife could not stand her at all. She didn't even give her food properly. This way the dispute with his wife started. His wife thought he was giving all his money to us. [-] She spreads propaganda that he has a relationship with me. But see, he's like my own child. He tried to make his wife understand many times that I am like his mother. But his wife didn't understand. She kicked him out of the house. [-] Zohur used to say, "there is trouble even if I stay here, or move there."

Another example comes from Arun who was unable to meet the excessive demands of his wife from the earnings of his small business. She used to undermine and verbally abuse him. Following an altercation between them she would go to her parents' home. On some occasions Arun had to seek assistance from the local leaders or the elderly to bring her back. Referring to Arun's suicide, his mother, Sandha, informed the interviewer:

He was so inclined to his wife that after a few days he again along with one of his uncles went to his father in law's house to bring his wife back. His wife and in-laws were very harsh with him. They even did not allow them to get into the home. He came back home and out of shame, disgrace and anger committed suicide at around 2:00 in the morning. Before committing suicide, Arun called his wife 161 times through his cell phone but she did not respond to his call even for a single time.

\section{Sexual Impotency and Infidelity}

The ability to perform sexually and to produce offspring is considered an important indicator of hegemonic masculinity (Adinkrah, 2012). Men who fail to perform sexually are likely to be socially positioned as the bearer of marginalised, subordinate forms of masculinity resulting in humiliation and despair (Flood, 2002). 
In the study some suicides were reported to have occurred due to men's sexual impotence or infidelity. One such case was that of Kader, a newly married young man. According to Simi, Kader's mother, Kader's marriage was very short-lived. Simi assumed that Kader's suicide was most likely caused by his sexual troubles. Simi stated that:

Kader was very thin in stature and was not physically strong. A man has to keep his wife happy in every way. [-] I could foresee them having a lot of troubles. My son was younger in terms of age to his wife. It's just not merely her age, she had a lot of demands. [-] I was informed by some sources of the fact that her physical/sexual demands were unmet. She didn't want to engage in a sort of sexual activity with Kader. Quickly, the intensity of the disputes between them had increased. [-] SOVA NGO workers tried to make her understand to stay in this relationship but it all went in vain. Her only words were, "I don't want to stay in this relationship with Kader". My son tried to keep her home at his best. But it did not work at all.

Ahsan also faced sexual/physical problems which allegedly caused his wife Chitra to get involved with a neighbour. Once he discovered this, Ahsan tried to convince Chitra to come back. Ahsan threatened to commit suicide if Chitra did not end her relationship. Chitra described what happened in the following way:

My husband had a physical problem and my sexual dissatisfaction led me to thatrelation. Secondly, I thought that he was just trying to frighten me and wouldnever commit suicide. So I continued my extramarital relationship.

Similarly, Ahmed, Sharif's father reported that Sharif's wife maintained her previous romantic relationship with her cousin even after she married his son. Moreover, Sharif's wife used to frequently visit her parent's home and sometimes refused to come back. Ahmed described the situation as follows:

Surprisingly, he (Sharif) returned on the same day (the day he visited his father-inlaw's house) without accompanying her wife. I asked, "what happened?" $\mathrm{He}$ replied, "nothing". However, I realised there was a huge conflict between them which forced my son to come back on the same date. Later on, I came to know it from one of his friends that he gave an ultimatum to his wife that he would commit suicide if she does not come back in four days' time. I got concerned. I heard from his friend that one of the reasons as to why my daughter in law was least interested to come back home early once she visited her father's home is that she had maintained an affair with her cousin there. They had a quarrel on that issue there. Perhaps, that was also the reason as to why my son wanted to satisfy his wife with all his means. He was so scared about his family life. 


\section{Loss of Self-Esteem and Respect}

Loss of self-esteem and respect also emerged as suicidal factor. The relationship between suicide and self-esteem and respect manifests in relation to the gap between the ideal hegemonic pattern of masculinity and a crisis of manhood in reality (Scourfield \& Evans, 2014). Although loss of self-esteem and respect can also be inferred in several of the themes presented above, it was more explicit in certain cases. The centrality of self-esteem and respect can be understood in relation to the stronghold of patriarchy and male domination in Bangladesh (Rahman \& Khan, 2018). Loss of self-esteem and respect therefore produces distress among Bangladeshi men.

For example, Badal, Faiyaz's father, reported that his son had committed suicide following an argument with his wife. Badal narrated the events preceding his son's suicide as follows:

In the afternoon, they had a hot talk over the phone. I was not at home. Faiyaz's mother listened him talking indicating her wife -"what did he say?" "she told me tui" (a derogative word for addressing oneself), "I will go to Dhaka and will not return in five years" etc. Once I returned home, her mother explained me everything. I advised Faiyaz to calm down. But he did not talk much-he looked so devastated. I realised addressing tui [The literal meaning of tui is you. In Bangladeshi culture tui is a very degrading word in an intimate relationship] hurt him a lot. Can a wife say tui to his husband?

An intriguing case is that of Liton, as conveyed by Jahida, his mother. She said that her son Liton committed suicide following the perpetuation of physical violence against her by her husband. Liton tried to protect his mother but his father aggressively bit his hand and injured him. This occurred in front of Liton's newly married wife. After the incident, Liton immediately went out of the house and ingested pesticide. In describing the incident, Jahida said:

He was newly married. He was very ashamed as his wife saw everything. They were just married. Probably he thought that his wife could share this incident with her parents. If so, it would be so shameful for him. [-] In the hospital, I asked why he ate poison. He said, "why did father bite me in front of my wife. How can I face her?"

Dolli, Javed's wife, narrated how she and Javed's son took control of family finances following Javed's marriage to his second wife. This resulted in Javed becoming disinterested in family matters. Before this, Javed was in full control of the family. In addition, he was suffering from a severe stomach pain which required regular medication. One day his wife refused to give him money to buy medicine. Following the incident, Javed committed suicide. Dolli pointed to Javed's loss of honour in the following manner: 
He had regular stomach pain. He needed medication every day. For medicine he needed money every day. My son and I were trying hard to meet familial expenditures. The day before he committed suicide, he wanted money and I refused. [-] I said go to your second wife to have money. You can marry whenever you want because you are a man. But as a man why can't you earn for buying medicine? I think it hurts him. On that very night, he committed suicide hanging himself from the branch of a tree.

\section{Mental and Physical Illness}

Mental disorders and physical illnesses may be a triggering factor leading individuals to commit suicide (Fegg et al., 2016). A few men in our study appeared to have committed suicide as a result of suffering from long-term physical and mental illness. For instance, according to Borhan his friend Johny was reported to have developed schizophrenia. There a number of significant adverse events that had occurred in his life prior to the diagnosis of schizophrenia. These included his parents separation when he was a child, his failure to be accepted at university, inability to settle into professional life, failure to develop friendships, feeling humiliation at friends' success, damage to his upper-gum and teeth, his inability to provide for his family financially and dependence on mother for monetary needs, and an addiction to drugs. Borhan narrated the following:

He could not adjust to anything. He was not a normal person. In my opinion a mancommits suicide when he lost confidence in himself-exactly that happened to my friend.There were a series of events in his life that led him to commit suicide. [-] Escaping from life is a failure. He failed from the battlefield of life. Fighting in the battlefield is the demonstration of manhood. In this sense, he lost his manhood in all means.

Taher, who was a capable provider, also became distressed when he encountered serious physical illness due to a stomach ulcer. This illness diminished his earning ability. The unbearable stomach pain was given as the reason for his suicide. Sultana, Taher's wife explains:

A couple of days before his suicide he started having severe stomach pain. He was moaning that he does not want to live anymore. He started saying that "I don't want to engage more searing pain." I think he was burning inside. The medicines were not working properly. Towards the end he couldn't even eat. On that day, I had gone to my neighbour's house in the morning. Suddenly, I heard my daughter shouting. During this time, he ingested pesticide. His condition was very severe when I returned home. We took him to the hospital immediately. But we couldn't have known that everything has ended. 


\section{Personal Sacrifice for the Good and Stability of the Family}

Participants spoke of men sacrificing themselves for the sake of the family. Sacrifice involves providing a positive benefit for another individual or a relationship by subordinating one's own personal interests or incurring personal loss (Killen \& Turiel, 1998). Historically, sacrifice has comprised a crucial component of masculinity (Munroe, 2001). Interestingly, accounts of suicide as sacrifice were not linked with sacrifice as understood in Islam given that the explicit prohibition against suicide in the Quran (Sarfraz \& Castle, 2002; Shah \& Chandia, 2010). While suicide and martyrdom/sacrifice are conflated in conflict zones (Hamamra, 2018), the participants did not relate the sacrifice of the men who had committed suicide to martyrdom. This may be due to the fact that the self-sacrifice (suicide) was related to familial/social issues rather than religious ones. Acia, the mother of Fakrul, an 18-year-old young man who developed an interest in family farming, shared a very unique example of sacrificing oneself for the good of the family. According to Acia, at one point three cows of the family died in quick successions, which made Frakrul very upset. Fakrul believed that the cows had died as a result of revenge taken by the mother of a snake that was killed by his mother. He thought that in order to get rid of the curse and protect the family from further loss he should sacrifice himself. His mother, Acia, explained:

My son left a small note before committing suicide stating that he is concerned about the frequent death of the cows. He also wrote that if he dies the dead snake and its mother would not take any revenge over his family. The loss of the family might be recovered by his death [-]. My son sacrificed his life for the sake of the family.

\section{Discussion}

All six of the themes demonstrate the dynamic interplay between hegemonic masculinity and suicide. The first theme, failing providers, demonstrates how suicides were related to the financial incapability or constraints. This is an example of how having money and work is an important symbol of hegemonic masculinity (Scourfield et al., 2012). Within this context, we found that the troubles associated with men's provider responsibility operated as a critical risk factor for suicide. The men's failure to fulfil expectations as primary providers undermined their masculine status, as has been demonstrated in other research (e.g. Andoh-Arthur et al., 2018; Niehaus, 2012; Rivers, 2014).The findings of this study are also supported by Stack's (2000) 15-year sociological review on suicide that confirms men's suicide is connected to the greater visibility of failure in the perceived primary adult male role. 
Related to the centrality of financial provision, unmanageable debt, which is often stressful as well as humiliating (McDaid, 2017), is another risk factor for suicidal behaviour. Some men in this study were trapped by the debt they incurred in attempts to fulfill their financial responsibilities to their families. In the South African context, Neihaus (2012) found a sharp connection between male suicide and harsh economic realities including the burden of debt, with the inability to settle debt preceding suicide in men. Similarly, in India it has been documented that indebtedness is a principal factor for male farmers' suicide (Merriot, 2016).

It is worth noting that almost all men who died by suicide were from lower socio-economic background and involved in farming, small business, low-skill or manual labour. Thus, their breadwinner status was aggravated by economic hardships and poverty, coupled with apparent disrespect from family members concerning their roles as financial providers. These findings are supported by Alston's (2012) study in Australia which noted that a growing number of rural farming men take their lives when they fail to cope with drought, low production and lack of income. These examples attest to the fact that men's perceived deviation from the normative masculine primary provider role can promote suicidal behaviour. Suicide is thus perceived as a means to escape from social responsibility and shame for men who feel that they have failed to live up to the gendered social expectations of financial provision, resulting in their loss of their (hegemonic) masculinity (Dolan, 2009).

The second theme relationship strain highlights the troubles men encountered in their intimate relationships. Relationship strain has been found to be a critical risk factor for suicidal behaviour (Knizek \& Hjelmeland, 2018). Research suggests that when there is a gap between expectation and reality in relationships, men might react in self-destructive ways, including through suicide (Scourfield \& Evans, 2015). Several studies such as Evans et al.(2016), Scourfield (2005) and Andoh-Arthur et al. (2018) confirm that men are at greater risk for suicide than women due to relationship breakdown and related strains. Our study further supports this finding and suggest that relationship strain may be mediated by men's material positions. Therefore, relationship strain and breakdown occur in relation to men's failure to meet the gendered expectations of their relationships, including that of financial provision (Scourfield \& Evans, 2015).

The theme of sexual impotency and infidelity highlights another kind of masculinity crisis. A few men's suicides were attributed to the anxiety and shame associated with sexual dysfunctions, which sometimes resulted in their wives' infidelity. Sexual performance is crucial for demonstrating male power and successful masculinity (Philaretou \& Allen, 2001). The hegemonic model of (heterosexual) masculinity can be undermined by failure to perform sexually (Kimmel, 1987), as the basis of hegemonic masculine sexuality is contingent upon the assessment of success in sex (Pott, 2000). In Bangladeshi patriarchal society the degree of men's superiority over women is determined by, among 
others, the ways men can demonstrate their sexual potency (Khan et al., 2008). Sexual achievement is thus one of the key indicators which embodies hegemonic masculinity in Bangladesh (Imtiaz, 2013). From the empirical findings on married and unmarried men's sexual performance in Bangladesh, Khan et al. (2008) found that most of the participants had serious anxieties with their sexual competence/performance and viewed it as a threat to masculinity. However, findings of our study also suggest that men's impotency is strongly correlated with wives' infidelity, which may then become a motivating factor for suicide for some men. Examples with regard to sexual impotency, infidelity and suicide are consistent with other literature on masculinity and suicide (Adinkrah, 2012; Andoh-Arthur et al., 2018). Sexual impotency and infidelity is also closely related to the previous theme suppression through relationship crisis/strain, with impotency and infidelity leading to relationship problems and even breakdown.

Loss of masculine self-esteem and respect was another theme identified in our study. In most cases, losing honour or respect occurred in relations with women. In Bangladesh society patriarchal norms and values are related to notions of female subordination, subservience, subjugation and segregation (Sultana, 2011). Within this context, men's suicide can be seen to be related to their wives lack of subservience, which results in loss of male social power and positions as 'real men' (Connell, 1995). Other research has demonstrated that a loss of self-esteem and respect through entrapment, disempowerment and defeat are strongly associated with suicidal behaviour (Taylor et al., 2011). Our research suggests that men's sufferings was aggravated when they perceived that they were dishonoured by members of their family. This is an example of how honour is integral to some forms of (hegemonic) masculinity. Evidence confirms that a suicidal event is more likely to occur if a man perceives a loss of honour (Platt, 2017).

Physical and mental illness was an important theme of this study. Men's illness is strongly related to hegemonic masculinity. Illness can badly affect men's position in masculine hierarchies, as the hegemonic ideals regarding health uphold the cultural beliefs that men are more powerful and less vulnerable than women (Charmaz, 1995; Courtenay, 2000). The material body is a central component of hegemonic masculinity, thus when the physical body becomes ill or disabled, the constitution of hegemonic masculinity becomes vulnerable (Connell, 1995). Mental illness is also a challenge to hegemonic masculinity, with men who are mentally ill falling into the category of subordinated masculinity (Featherstone et al., 2007). Simultaneously, both mental and physical illness may disrupt men's ability to fulfil hegemonic roles as providers and protectors. Therefore, suicide may operate as a way for men to escape not only the extreme physical or mental suffering (Cheatle, 2011), but also their failed masculinity. 
The personal sacrifice for the good and stability of the family theme provides a unique contextual understanding on the ways men sacrificed their lives out of altruistic motivation for the sake of the family or relationship. Self-sacrifice is a robust feature that protects the value of familism (Nolle et al., 2012). This kind of altruism/sacrifice has been found to be an essential attribute of dominant masculinity (Niehaus, 2012). Suicide for altruistic/self-sacrificial reasons can be seen to be linked to expectations of masculine honour. For example, in the case where men fail to fulfil their masculine responsibilities, failing to commit suicide may be perceived as dishonorable and unmasculine - a refusal to sacrifice the self for the good of others (Durkheim, 1951). Suicide out of the motivation of self-sacrifice is condoned in the context of excessive social integration, where the individual's needs resubverted to the point of deindividuation (Stack, 2004). However, as we have highlighted above, notions of masculine sacrifice may be in conflict with religious expectations which prohibit suicide. We return to this below.

Although religion was not explicitly spoken about in the interviews, we suggest that it plays a role in the relationship between masculinity and suicide in the wider context of Bangladesh. Of the 20 men who committed suicide, 18 of them were Muslims. In Islam suicide is considered as a major sin as there is nothing more precious than life. Thus, a true believer in Islam is not allowed to take his or her own life (Rahman et al., 2012). The Quran explicitly forbids individuals from killing themselves and warns that individuals who take their own lives will have to serve in hell perpetually and never be forgiven (Freamon, 2003; Kamal \& Lowenthal, 2002). Islam also vividly distinguishes between sacrifice that leads to martyrdom and suicide. Suicide is not a sacrifice or may not be treated as martyrdom unless it is embedded in the philosophy of religion. In contrast to those who commit suicide, those who sacrifice their lives for the greater cause of the religion or God do not actually die but rather proceed directly to paradise (Freamon, 2003; Gearing \& Lizardi, 2009). Analysing the evidence and context of the suicide cases, the notion of sacrifice in some of the accounts is misaligned to the meaning of sacrifice found in Islamic interpretations. Within this context, the suicide of Muslim men may in fact operate as both an unmanly act and a failure before God. This example also highlights the way in which multiple, and sometimes even contradictory, social factors shape local understandings of masculinity. Therefore, men may face conflicting notions of masculine sacrifice which may result in increased frustration and shame, potentially leading to suicide.

\section{Limitations}

There are several limitations of our study. As a qualitative study, conducted in a specific rural location, the findings are unsuitable for making generalisations to the population of suicidal men in Bangladesh. The likelihood of recall or report 
biasness is also a shortcoming of this study as it is retrospective, relying on the narratives of others. Furthermore, only one person for each suicide case who is close to the deceased was interviewed. If several family members were interviewed, data would have been adequately triangulated. Notwithstanding these limitations, our study has advanced significant theoretical, methodological and policy implications.

\section{Conclusion}

This is the first qualitative study in Bangladesh that provides insight into subjective meanings about the relationship between suicide and masculinity, which is a key component of the socio-cultural context - including religious aspects of that context. The study contributes to the filling the gap in sociological knowledge and understandings of suicide in Bangladesh (see, Khan et al., 2020b). Findings of the study reveal that suicidal events were principally associated with men's failure to fulfil social expectations of hegemonic masculinity.

Our findings point to key issues in relation to suicide prevention. The rigid and restrictive dichotomisation associated with gender roles needs to be countered in order to reduce rates of male suicide, as such restrictive expectations could be extremely health-damaging for men. Furthermore, men are reputedly at greater risk for suicide because the socio-culturally learnt norms of masculinity restrict their ability to seek supports or disclose feelings (Cleary, 2012). In Bangladesh, where no specific strategy to reduce suicidal behaviour currently exists, it is important to develop a strategy that includes critical issues related to hegemonic masculinity. Hegemonic masculinity does not precisely reflect the real lives of most men, but it remains a key reference point against which men are measured and measure themselves (Plester, 2015). Without challenging and reformulating norms related to hegemonic masculinity, high rates of male suicide are likely to persist. Finally, this study leaves us with the possibility of several future research directions in the context of masculinity and suicide. More importantly, considering the major religious faith (Islam) in Bangladesh future studies could explore in more details the complexities of suicide as a self-sacrifice rooted in the discourses of religious masculinity/heroism.

\section{Declaration of Conflicting Interests}

The author(s) declared no potential conflicts of interest with respect to the research, authorship, and/or publication of this article.

\section{Funding}

The author(s) received no financial support for the research, authorship, and/or publication of this article. 


\section{ORCID iD}

Anisur Rahman Khan (D) https://orcid.org/0000-0001-8154-0284

\section{References}

Adinkrah, M. (2012). Better dead than dishonoured: Masculinity and male suicidal behaviour in contemporary Ghana. Social Science \& Medicine (1982), 74(4), 474-481. https://doi.org/10.1016/j.socscimed.2010.10.011

Andoh-Arthur, J., Knizek, B. L., Osafo, J., \& Hjelmeland, H. (2018). Suicide among men in Ghana: The burden of masculinity. Death Studies, 42(10), 658-666. https://doi.org/ $10.1080 / 07481187.2018 .1426655$

Anwary, A. (2015). Construction of hegemonic masculinity: Violence against wives in Bangladesh. Women's Studies International Forum, 50, 37-46. https://doi.org/10.1016/ j.wsif.2015.02.011

Arafat, S., Mali, B., \& Akter, H. (2020). Characteristics, methods and precipitating events of suicidal behaviors in Bangladesh: A year-round content analysis of six national newspapers. Neurology, Psychiatry and Brain Research, 36, 14-17. https:// doi.org/10.1016/j.npbr.2020.02.005

Bangladesh Bureau of Statistics (2015). Population monograph of Bangladesh. http:// 203.112.218.65:8008/WebTestApplication/userfiles/Image/PopMonographs/Volume9_Age-Sex.pdf

Bantjes, J., \& Kagee, A. (2013). Epidemiology of suicide in South Africa: Setting an agenda for future research. South African Journal of Psychology, 43(2), 238-251. https://doi.org/10.1177/0081246313482627

Bantjes, J., \& Swartz, L. (2017). The cultural turn in critical suicidology: What can we claim and what do we know? Death Studies, 41(8), 512-520. https://doi.org/10.1080/ 07481187.2017 .1333355

Braun, V., \& Clarke, V. (2006). Using thematic analysis in psychology. Qualitative Research in Psychology, 3(2), 77-101. https://psycnet.apa.org/doi/10.1191/1478088 706qp063oa

Canetto, S. S., \& Cleary, A. (2012). Introduction: Men, masculinities and suicidal behaviour. Social Science \& Medicine (1982), 74(4), 461-465. https://doi.org/10.1016/j.socs cimed.2011.11.001

Charmaz, K. (1995). Identity dilemmas of chronically ill men. In D. Sabo \& D. F. Gordon (Eds.), Men's health and illness: Gender, power and the body (pp. 266-291). Sage.

Cheatle, M. D. (2011). Depression, chronic pain, and suicide by overdose: On the edge. Pain Medicine, 12(suppl 2), S43-S48. https://doi.org/10.1111/j.1526-4637.2011. 01131.x

Clearly, A. (2019). The gendered landscape of suicide: Masculinities, emotions and culture. Palgrave Macmillan.

Cleary, A. (2012). Suicidal action, emotional expression, and the performance of masculinities. Social Science \& Medicine (1982), 74(4), 498-505. https://doi.org/10.1016/j. socscimed.2011.08.002

Clowes, L., Ratele, K., \& Shefer, T. (2013). Who needs a father? South African men reflect on being fathered. Journal of Gender Studies, 22, 255-267. https://doi.org/10. $1080 / 09589236.2012 .708823$ 
Connell, R. W. (1995). Masculinities. Berkley: University of California Press.

Courtenay, W. H. (2000). Constructions of masculinity and their influence on men's wellbeing: A theory of gender and health. Social Science \& Medicine, 50(10), 1385-1401. https://doi.org/10.1016/s0277-9536(99)00390-1

Demir, M. (2018). Gender differences in suicide rates. Forensic Science \& Addiction Research, 2(4), 161-165. http://dx.doi.org/10.31031/fsar.2018.02.000550

Dermott, E. (2008). Intimate fatherhood: A sociological analysis. Routledge.

Dolan, C. (2009). Social torture: The case of Northern Uganda 1986-2006. Berghahn Books.

Doneys, P. (2013). Masculinity and gender-based violence in Bangladesh. http://www.part ners4prevention.org/sites/default/files/resources/bangladesh_qualitative_workingpa per_final.pdf

Durkheim, E. (1951). Suicide: A study in sociology. The Free Press.

Evans, R., Scourfield, J., \& Moore, G. (2016). Gender, relationship breakdown, and suicide risk. Journal of Family Issues, 37(16), 2239-2264. https://doi.org/10.1177/ $0192513 \times 1456260$

Featherstone, B., Rivett, M., \& Scourfiled, J. (2007). Working with men in health and social care. Sage.

Fegg, M., Kraus, S., Graw, M., \& Bausewein, C. (2016). Physical compared to mental diseases as reasons for committing suicide: A retrospective study. BMC Palliative Care, 15(1), 14. https://doi.org/10.1186/s12904-016-0088-5

Flood, M. (2002). Between men and masculinity: an assessment of the term "masculinity" in research scholarship on men. In S. Pearce \& V. Muller (Eds.), Manning the next millennium: Studies in masculinities (pp. 203-213). Black Swan Press.

Freamon, B. K. (2003). Martyrdom, suicide, and the Islamic law of war: A short legal history. Fordham International Law Journal, 27(1), 229-369.

Gearing, R., \& Lizardi, D. (2009). Religion and suicide. Journal of Religion and Health, 48(3), 332-341. https://doi.org/10.1007/s10943-008-9181-2

Gearing, R., \& Alonzo, D. (2018). Religion and suicide: New findings. Journal of Religion and Health, 57(6), 2478-2499. https://doi.org/10.1007/s10943-018-0629-8

Hamamra, B. T. (2018). Witness and martyrdom: Palestinian female martyrs' video-testimonies. Journal for Cultural Research, 22(3), 224-238. https://doi.org/10.1080/ 14797585.2018.1511941

Hasan, M. K., Aggleton, P., \& Persson, A. (2018). The makings of a man: Social generational masculinities in Bangladesh. Journal of Gender Studies, 27(3), 347-361. https://doi.org/10.1080/09589236.2017.1388773

Imtiaz, S. S. (2013). Ordinary men's constructions of masculinity: Exploration of constructions of masculinity in extreme poor household in Northeast Bangladesh. http:// www.care.org/sites/default/files/documents/Bangladesh\%20EMI\%20report.pdf.

Jaworski, K. (2010). The gendering of suicide. Australian Feminist Studies, 25(63), 47-61. https://doi.org/10.1080/08164640903499752

Kamal, Z., \& Loewenthal, K. M. (2002). Suicide beliefs and behavior among young Muslims and Hindus in the UK. Mental Health, Religion, and Culture, 5(2), 111-118. https://doi.org/10.1080/13674670210141052

Killen, M., \& Turiel, E. (1998). Adolescents' and young adults' evaluations of helping and sacrificing for others. Journal of Research on Adolescence, 8(3), 355-375. https:// doi.org/10.1207/s15327795jra0803_4 
Kimmel, M. (1987). Changing men: New directions in research on men and masculinity. Sage.

Khan, A. R., Ratele, K., Arendse, N., Islam, M. Z., \& Dery, I. (2020a). Suicide and attempted suicide in Jhenaidah District, Bangladesh, 2010-2018. Crisis: The Journal of Crisis Intervention and Suicide Prevention, 41(4), 304-312.https://doi.org/10.1027/ 0227-5910/a000631

Khan, A. R., Ratele, K., \& Dery, I. (2020b). (Re)animating sociology of suicide in Bangladesh, Italian Sociological Review, 10 (1), 55-75. http://dx.doi.org/10.13136/ isr.v10i1.317

Khan, A. R., Ratele, K., \& Arendse, N. (2020c). Men's reflections on postsuicide attempt episode in Bangladesh. OMEGA - Journal of Death and Dying. Advance online publication. https://doi.org/10.1177/0030222820904878

Khan, M. E., \& Townsend, J. W. (2014). Representation of 'masculine' identity in Bangladesh. In M. E. Khan, J. W. Townsend, \& P. J. Pelto (Eds.) Sexuality, gender roles and domestic violence in South Asia (pp. 118-132). Population Council.

Khan, S. I., Hudson-Rodd, N., Saggers, S., Bhuiyan, M. I., Bhuiya, A., Karim, S. A., \& Rauyajin, O. (2008). Phallus, performance and power: Crisis of masculinity. Sexual and Relationship Therapy, 23(1), 37-49. http://dx.doi.org/10.1080/14681990701790635

Knizek, B. L., \& Hjelmeland, H. (2018). To die or not to die: A qualitative study of men's suicidality in Norway. BMC Psychiatry, 18(1), 263. https://doi.org/10.1186/s12888018-1843-3

Koenig, H. G., \& Al Shohaib, S. (2014). Health and well-being in Islamic societies. Springer.

Latakienè, J., \& Skruibis, P. (2015). Attempted suicide: Qualitative study of adolescent females' lived experience. International Journal of Psychology : A Biopsychosocial Approach, 17, 79-96. https://doi.org/10.7220/2345-024X.17.5

Lester, D. (2006). Suicide and Islam. Archives of Suicide Research: Official Journal of the International Academy for Suicide Research, 10(1), 77-97. https://doi.org/10.1080/ 13811110500318489

Mansdotter, A., Lundin, A., Falkstedt, D., \& Hemmingsson, T. (2009). The association between masculinity rank and mortality patterns: A prospective study based on the Swedish 1969 conscript cohort. Journal of Epidemiology and Community Health, 63(5), 408-413. https://doi.org/10.1136/jech.2008.082628

Mashreky, S. R., Rahman, F., \& Rahman, A. (2013). Suicide kills more than 10,000 people every year in Bangladesh. Archives of Suicide Research: Official Journal of the International Academy for Suicide Research, 17(4), 387-396. https://doi.org/10.1080/ 13811118.2013 .801809

McDaid, D. (2017). Socioeconomic disadvantage and suicidal behaviour during times of economic recession and recovery. http://eprints.lse.ac.uk/69795/1/McDaid_ Socioeconomic\%20disadvantage $\% 20$ and $\% 20$ suicidal\%20behaviour_published_2017 $\% 20$ LSERO \%20edit.pdf

Merriott, D. (2016). Factors associated with the farmer suicide crisis in India. Journal of Epidemiology \& Global Health, 6(4), 217-227. https://doi.org/10.1016/j. jegh.2016.03.003

Morgan, D. (2006). The crisis in masculinity. In K. Davis, M. Evans, J. Lorber (Eds) Handbook of gender and women's studies (pp. 109-124). Sage. 
Munroe, J. (2001). Understanding the purpose and power of men a book for men and the women who love them. Whitaker House.

Naghavi, M. (2019). Global, regional, and national burden of suicide mortality 1990 to 2016: Systematic analysis for the Global Burden of Disease Study. BMJ, 364, 194. https://doi.org/10.1136/bmj.194

Niehaus, I. (2012). Gendered endings: Narratives of male and female suicides in the South African Lowveld. Culture, Medicine and Psychiatry, 36(2), 327-347. https:// doi.org/10.1007/s11013-012-9258-y

Nolle, A. P., Gulbas, L., Kuhlberg, J. A., \& Zayas, L. H. (2012). Sacrifice for the sake of the family: Expressions of familism by latina teens in the context of suicide. The American Journal of Orthopsychiatry, 82(3), 319-327. https://doi.org/10.1111/j.19390025.2012.01166.x.

Pirkis, J., Spittal, M. J., Keogh, L., Mousaferiadis, T., \& Currier, D. (2017). Masculinity and suicidal thinking. Social Psychiatry and Psychiatric Epidemiology, 52(3), 319-327. https://doi.org/10.1007/s00127-016-1324-2

Philaretou, A., \& Allen, K. (2001). Reconstructing masculinity and sexuality. The Journal of Men's Studies, 9(3), 301-321. https://doi.org/10.3149/jms.0903.301

Platt, S. (2017, August). Suicide in men: What is the problem? Trends in Urology \& Men's Health, 8(4), 9-12.

Plester, B. (2015). 'Take It like a Man!': Performing hegemonic masculinity through organisational humour. Ephemera: Theory \& Politics in Organisation, 15(3), 537-559.

Pompili, M. (2018). Reflections of a committed suicidologist. In M. Pompili (Ed.), Phenomenology of suicide (pp. 13-30). Springer.

Potts, A. (2000). The essence of the hard on. Men \& Masculinities, 3(1), 85-103. https:// doi.org/10.1177/1097184x00003001004

Rahman, A., Ahmad, W., Mohamad, S., \& Muhamad, R. (2012). Insurability and suicide: Shariah issues in underwriting. Procedia - Social and Behavioral Sciences, 65, 593-601. https://doi.org/10.1016/j.sbspro.2012.11.170

Rahman, M. M., \& Khan, A. R. (2018). Challenges and coping strategies of women leaders in Bangladesh. Italian Sociological Review, 8 (1), 43-63. http://dx.doi.org/10. 13136/isr.v8i1.155

Rivers, J. (2014). Suicide and hegemonic masculinity in Australian men. In D. Lester, J. F. Gunn III, \& P. Quinnett (Eds.), Suicide in men (pp. 248-261). Charles C. Thomas.

Rossman, G. B., \& Rallis, S. F. (2012). Learning in the field: An introduction to qualitative research. Sage.

Rutz, W., \& Rihmer, Z. (2007). Suicidality in men - Practical issues, challenges, solutions. The Journal of Men's Health \& Gender, 4(4), 393-401. https://doi.org/10.1016/j. jmhg.2007.07.046

Salam, S. S., Alonge, O., Islam, M. I., Hoque, D. M., Wadhwaniya, E. S., Baset, M. K. U., Mashreky, S. R., \& Arifeen, S. E. (2017). The burden of suicide in rural Bangladesh: Magnitude and risk factors. International Journal of Environmental Research and Public Health, 14(9), 1032. https://doi.org/10.3390/ijerph14091032

Sarfraz, M. A., \& Castle, D. (2002). A Muslim suicide. Australasian Psychiatry, 10(1), 48-50. https://doi.org/10.1046\%2Fj.1440-1665.2002.00392.x

Scourfield, J. (2005). Suicidal masculinities. Sociological Research Online, 10(2), 1-14. https://doi.org/10.5153/sro.1057 
Scourfield, J., \& Evans, R. (2015). Why might men be more at risk of suicide after a relationship breakdown? Sociological insights. American Journal of Men's Health, 9(5), 380-384. https://doi.org/10.1177\%2F1557988314546395

Scourfield, J., Fincham, B., Langer, S., \& Shiner, M. (2012). Sociological autopsy: An integrated approach to the study of men. Social Science \& Medicine (1982), 74(4), 466-473. https://doi.org/10.1016/j.socscimed.2010.01.054

Shah, A., \& Chandia, M. (2010). The relationship between suicide and Islam: A crossnational study. Journal of Injury \& Violence Research, 2(2), 93-97. https://doi.org/10. 5249 /jivr.v2i2.60

Sherman, R. M., D’Orio, B., Rhodes, M. N., Johnson, S. G., \& Kaslow, N. J. (2008). Racial/ethnic, spiritual/religious, and sexual orientation influences on suicidal behaviors. In M. Nock (Ed.) The Oxford handbook of suicide and self-injury (pp 265-285). Oxford University Press.

Sowad, A. S. M. (2017). Influences of emerging beauty industry for men on construction of masculinities of male students of Dhaka city. Masculinities \& Social Change, 6(1), 1-16. http://dx.doi.org/10.17583/mcs.2017.2290

Stack, S. (2000). Suicide: A 15-year review of the sociological literature part I: Cultural and economic factors. Suicide \& Life-Threatening Behavior, 30(2), 145-162. https:// doi.org/10.1111/j.1943-278X.2000.tb01073.x

Stack, S. (2004). Emile Durkheim and altruistic suicide. Archives of Suicide Research: Official Journal of the International Academy for Suicide Research, 8(1), 9-22. https:// doi.org/10.1080/13811110490243741

Struszczyk, S., Galdas, P. M., \& Tiffin, P. A. (2019). Men and suicide prevention: A scoping review. Journal of Mental Health , 28(1), 80-88. https://doi.org/10.1080/ 09638237.2017.1370638

Sultana, A. (2011). Patriarchy and women's subordination: A theoretical analysis. The Arts Faculty Journal, 4, 111.

Taylor, P. J., Gooding, P., Wood, A. M., \& Tarrier, N. (2011). The role of defeat and entrapment in depression, anxiety, and suicide. Psychological Bulletin, 137(3), 391-420. https://psycnet.apa.org/doi/10.1037/a0022935

Vijayakumar, L. (2015). Suicide in women. Indian Journal of Psychiatry, 57(Suppl 2), S233-S238. http://doi.org/10.4103/0019-5545.161484

White, J., Kral, M., Marsh, I., \& Morris, J. (2016). Introduction: Rethinking suicide. In J. White, M. Kral, I. Marsh, \& J. Morris (Eds.), Critical suicidology. Transforming suicide research and prevention for the 21st century (pp. 1-11). University of British Columbia Press.

World Health Organization. (2017). Preventing suicide: A resource for media professionals. http://apps.who.int/iris/bitstream/10665/258814/1/WHO-MSD-MER-17.5-eng. pdf?ua $=1$.

World Health Organization (n.d). Age-standardized suicide rates (per 100,000). https:// www.who.int/data/gho/data/indicators/indicator-details/GHO/age-standardized-sui cide-rates-(per-100-000-population)

Wray, M., Colen, C., \& Pescosolido, B. (2011). The sociology of suicide. Annual Review of Sociology, 37(1), 505-528. https://doi.org/10.1146/annurev-soc-081309-150058 


\section{Author Biographies}

Anisur Rahman Khan is an assistant professor at the Department of Sociology, East West University, Dhaka, Bangladesh. His research interests focus on men and masculinities, suicidal behaviour and social policy analysis. He worked as a postdoctoral research fellow at Masculinity and Health Research Unit, South African Medical Research Council-University of South Africa/Institute for Social and Health Sciences, University of South Africa, Cape Town, South Africa.

Kopano Ratele is the director of the South African Medical Research Council Masculinity \& Health Research Unit and professor at the University of South Africa where he runs the Transdisciplinary African Psychologies Programme. He has published extensively and his books include There Was This Goat: Investigating the Truth Commission Testimony of Notrose Nobomvu Konile (2009, co-authored with Antjie Krog and Nosisi Mpolweni), Liberating Masculinities (2016), Engaging Youth in Activism, Research and Pedagogical Praxis: Transnational and Intersectional Perspectives on Gender, Sex, and Race (2018, co-edited with Jeff Hearn, Tammy Shefer, and Floretta Boonzaier) and The World Looks Like This From Here: Thoughts on African Psychology (2019).

Rebecca Helman is a PhD candidate at the University of South Africa (UNISA). Her research interests include gender, sexualities and violence in "post-colonial" contexts.

Sipho Dlamini is a counselling psychologist and a lecturer in the Department of Psychology at the University of Johannesburg. His research interests include Africa(n)-centered Psychology, racialisation and racism, the history and philosophy of psychology, and higher education.

Refiloe Makama is a lecturer and $\mathrm{PhD}$ candidate in the Department of Psychology at the University of South Africa. Her interests are in masculinities studies, African feminism and African psychology. She is interested in narrative methodologies towards doing critical qualitative research. Her PhD explores the constructions, negotiations and enactments of gender and power within and through the customary practice of lobolo. 